\title{
Editorial
}

\section{Welcome to Seminars in Thrombosis \& Hemostasis 2013}

\author{
Emmanuel J. Favaloro, PhD, FFSc (RCPA) ${ }^{1}$ \\ ${ }^{1}$ Department of Haematology, Institute of Clinical Pathology and \\ Medical Research (ICPMR), Westmead Hospital, Westmead, New \\ South Wales, Australia
}

Semin Thromb Hemost 2013;39:5-9.
Welcome to the start of another year with Seminars in Thrombosis \& Hemostasis (STH). This is my 5th year as Editor in Chief and my 8th year of editorial association with this journal, having previously served as a Regional Editor. This year we again celebrate with "some old and some new." Our current Senior Editors, Marcel Levi, Catherine P. M. Hayward, and Hau C. Kwaan, will continue in their existing roles as Senior Editors of this journal. Many of our Associate Editors are also staying on, but we have also received and accepted some resignations. Nobuo Sakuragawa from Japan has asked to be permitted to "retire" from his editorial duties, having served on the board for over a decade. Also leaving the board is Leo R. Zacharski, after nearly a decade on the board. Hideo Wada from Japan joined the board in mid-2012, in part, to take over editorial duties from Prof. Sakuragawa and he will continue in this role in 2013. Also relatively new to the board is Rüdiger E. Scharf, who also began his tenure in mid-2012, and, finally, Johannes Oldenburg, who begins his tenure in 2013 with this first issue. I sincerely thank both Nobuo Sakuragawa and Leo R. Zacharski for their past support for this journal and officially welcome Hideo Wada, Johannes Oldenburg, and Rüdiger E. Scharf to the STH board.

I also take this opportunity to thank Sangeeta PC, the Managing Editor for Thieme Medical Publishers, as well as her production team for their excellent editorial assistance, and Kelly Coffey, a Journals Coordinator for Thieme Medical Publishers, for additional support provided over the past year.

I think this is also a fitting time to reflect on our journal's Impact Factor, which for 2011 was 4.524 (-Fig. 1). This is the highest Impact Factor that STH has ever achieved. Notably, the ongoing positive trend also indicates that this journal continues to progress laudably. I have previously highlighted, ${ }^{1,2}$ and would continue to assert, that the Impact Factor is not the only marker of journal quality that we should consider, given the existence of other biometric markers and the limitations of any individual marker (including the Impact Factor) as an indicator of journal quality. Nevertheless, for those of you

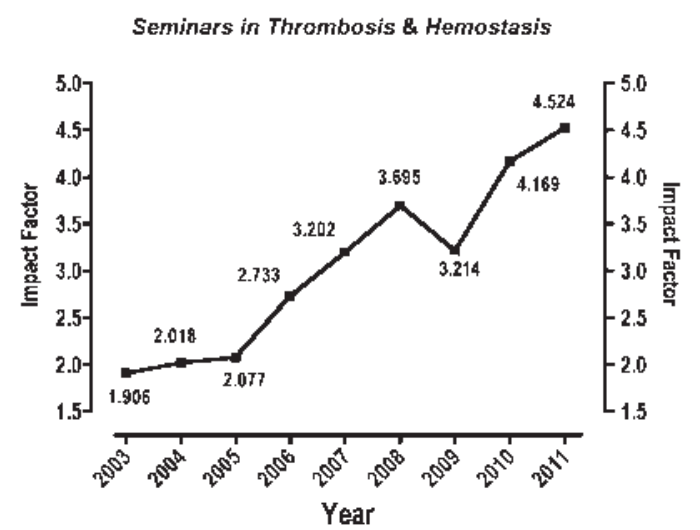

Fig. 1 Impact Factor for Seminars in Thrombosis \& Hemostasis for the period 2003 to 2011.

who may be interested, the top 52 listings of 2011-cited (2009/2010 published) contributions from this journal are provided in - Table 1. ${ }^{3-54}$ These contributions can therefore be identified as those most contributing to the 2011 Impact Factor, and each were cited four or more times in 2011. Notably, the top 11 articles on the list were cited between 10 and 23 times each in 2011, and the first two contributions were cited an impressive 20 or more times. A quick glance of the list will also indicate that the issue most contributing to this achievement was "Diagnostic Evaluation of Platelet Function Disorders," 55 guest edited by Catherine Hayward in 2009. I therefore especially thank Catherine Hayward and all the contributors to this issue, as well as others highlighted in -Table 1. Nevertheless, a big thank you also to all other contributors, guest editors, and the editorial team for bringing us the content that makes Seminars in Thrombosis $\mathcal{E}$ Hemostasis.

The current listing ( $\mathbf{- T a b l e ~} \mathbf{1}$ ) can be compared with those of the most recently published top 50 downloaded article

\footnotetext{
Address for correspondence and Issue Theme Hot Topics IV; Guest reprint requests Emmanuel ]. Editor, Emmanuel J. Favaloro, PhD, Favaloro, PhD, FFSc (RCPA), Department of Haematology, FFSC (RCPA)

Institute of Clinical Pathology and

Medical Research (ICPMR),

Westmead Hospital, Westmead,

NSW, 2145, Australia (e-mail:

emmanuel.favaloro@swahs.

health.nsw.gov.au).
}

Copyright (C) 2013 by Thieme Medical Publishers, Inc., 333 Seventh Avenue, New York, NY 10001, USA. Tel: +1(212) 584-4662.
DOI http://dx.doi.org/ 10.1055/s-0032-1331158. ISSN 0094-6176.

published online December 26, 2012 
Table 1 Top 52 most highly cited articles in Seminars in Thrombosis \& Hemostasis ${ }^{\mathrm{a}}$

\section{Contributions}

1. Althaus K, Greinacher A. MYH9-related platelet disorders. Semin Thromb Hemost. 2009 Mar;35(2):189-203

2. McGlasson DL, Fritsma GA. Whole blood platelet aggregometry and platelet function testing. Semin Thromb Hemost. 2009 Mar;35 (2):168-80.

3. Cattaneo M. Light transmission aggregometry and ATP release for the diagnostic assessment of platelet function. Semin Thromb Hemost. 2009 Mar;35(2):158-67.

4. Gisondi P, Girolomoni G. Psoriasis and atherothrombotic diseases: disease-specific and non-disease-specific risk factors. Semin Thromb Hemost. 2009 Apr;35(3):313-24.

5. Harrison P, Mumford A. Screening tests of platelet function: update on their appropriate uses for diagnostic testing. Semin Thromb Hemost. 2009 Mar;35(2):150-7.

6. Targher G, Chonchol M, Miele L, Zoppini G, Pichiri I, Muggeo M. Nonalcoholic fatty liver disease as a contributor to hypercoagulation and thrombophilia in the metabolic syndrome. Semin Thromb Hemost. 2009 Apr;35(3):277-87.

7. Favaloro EJ. Internal quality control and external quality assurance of platelet function tests. Semin Thromb Hemost. 2009 Mar;35 (2):139-49.

8. Nurden AT, Fiore M, Pillois X, Nurden P. Genetic testing in the diagnostic evaluation of inherited platelet disorders. Semin Thromb Hemost. 2009 Mar;35(2):204-12.

9. Pai M, Hayward CP. Diagnostic assessment of platelet disorders: what are the challenges to standardization? Semin Thromb Hemost. 2009 Mar;35(2):131-8

10. Sobieraj-Teague M, O’Donnell M, Eikelboom J. New anticoagulants for atrial fibrillation. Semin Thromb Hemost. 2009 Jul;35(5): 515-24.

11. Isbister GK. Procoagulant snake toxins: laboratory studies, diagnosis, and understanding snakebite coagulopathy. Semin Thromb Hemost. 2009 Feb;35(1):93-103.

12. de Moerloose P, Neerman-Arbez M. Congenital fibrinogen disorders. Semin Thromb Hemost. 2009 Jun;35(4):356-66.

13. Gouw SC, van den Berg HM. The multifactorial etiology of inhibitor development in hemophilia: genetics and environment. Semin Thromb Hemost. 2009 Nov;35(8):723-34.

14. Israels SJ. Diagnostic evaluation of platelet function disorders in neonates and children: an update. Semin Thromb Hemost. 2009 Mar;35(2):181-8.

15. Weiss HJ. Impaired platelet procoagulant mechanisms in patients with bleeding disorders. Semin Thromb Hemost. 2009 Mar;35 (2):233-41.

16. Lippi G, Favaloro EJ, Franchini M, Guidi GC. Milestones and perspectives in coagulation and hemostasis. Semin Thromb Hemost. 2009 Feb;35(1):9-22.

17. Lippi G, Maffulli N. Biological influence of physical exercise on hemostasis. Semin Thromb Hemost. 2009 Apr;35(3):269-76.

18. Mariani G, Bernardi F. Factor VII deficiency. Semin Thromb Hemost. 2009 Jun;35(4):400-6.

19. Miller JL. Glycoprotein analysis for the diagnostic evaluation of platelet disorders. Semin Thromb Hemost. 2009 Mar;35(2):224-32.

20. Clauser S, Cramer-Bordé E. Role of platelet electron microscopy in the diagnosis of platelet disorders. Semin Thromb Hemost. 2009 Mar;35(2):213-23.

21. Favaloro EJ. Toward a new paradigm for the identification and functional characterization of von Willebrand disease. Semin Thromb Hemost. 2009 Feb;35(1):60-75.

22. Kershaw G, Jayakodi D, Dunkley S. Laboratory identification of factor inhibitors: the perspective of a large tertiary hemophilia center. Semin Thromb Hemost. 2009 Nov;35(8):760-8.

23. Mezzano D, Quiroga T, Pereira J. The level of laboratory testing required for diagnosis or exclusion of a platelet function disorder using platelet aggregation and secretion assays. Semin Thromb Hemost. 2009 Mar;35(2):242-54.

24. Prisco D, Grifoni E. The role of D-dimer testing in patients with suspected venous thromboembolism. Semin Thromb Hemost. 2009 Feb;35(1):50-9.

25. Favaloro EJ, Bonar R, Kershaw G, Duncan E, Sioufi J, Marsden K. Investigations from external quality assurance programs reveal a high degree of variation in the laboratory identification of coagulation factor inhibitors. Semin Thromb Hemost. 2009 Nov;35(8): 794-805.

26. Franchini M, Montagnana M, Manzato F, Vescovi PP. Thyroid dysfunction and hemostasis: an issue still unresolved. Semin Thromb Hemost. 2009 Apr;35(3):288-94.

27. Harenberg J. New anticoagulants in atrial fibrillation. Semin Thromb Hemost. 2009 Sep;35(6):574-85.

28. Karimi M, Bereczky Z, Cohan N, Muszbek L. Factor XIII Deficiency. Semin Thromb Hemost. 2009 Jun;35(4):426-38.

29. Kitchen S, Jennings I, Preston FE, Kitchen DP, Woods TA, Walker ID. Interlaboratory variation in factor VIII:C inhibitor assay results is sufficient to influence patient management: data from the UK national quality external assessment scheme for blood coagulation. Semin Thromb Hemost. 2009 Nov;35(8):778-85.

30. Meijer P, Verbruggen B. The between-laboratory variation of factor VIII inhibitor testing: the experience of the external quality assessment program of the ECAT foundation. Semin Thromb Hemost. 2009 Nov;35(8):786-93.

31. Viiala NO, Larsen SR, Rasko JE. Gene therapy for hemophilia: clinical trials and technical tribulations. Semin Thromb Hemost. 2009 Feb;35(1):81-92.

32. Adams M. Assessment of thrombin generation: useful or hype? Semin Thromb Hemost. 2009 Feb;35(1):104-10.

33. Blann A, Shantsila E, Shantsila A. Microparticles and arterial disease. Semin Thromb Hemost. 2009 Jul;35(5):488-96.

34. Franchini M, Lippi G, Favaloro EJ. Coagulopathies and thrombosis: usual and unusual causes and associations, part I. Semin Thromb Hemost. 2009 Apr;35(3):257-9. 


\section{Contributions}

35. Lippi G, Franchini M, Favaloro EJ. Unsuspected triggers of venous thromboembolism-trivial or not so trivial? Semin Thromb Hemost. 2009 Oct;35(7):597-604.

36. Spreafico M, Peyvandi F. Combined factor V and factor VIII deficiency. Semin Thromb Hemost. 2009 Jun;35(4):390-9.

37. Tripodi A, van den Besselaar A. Laboratory monitoring of anticoagulation: where do we stand? Semin Thromb Hemost. 2009 Feb;35 (1):34-41.

38. Zuern CS, Lindemann S, Gawaz M. Platelet function and response to aspirin: gender-specific features and implications for female thrombotic risk and management. Semin Thromb Hemost. 2009 Apr;35(3):295-306.

39. Brand-Miller J, Dickinson S, Barclay A, Allman-Farinelli M. Glycemic index, glycemic load, and thrombogenesis. Semin Thromb Hemost. 2009 Feb;35(1):111-8.

40. Chitlur M, Lusher J. Standardization of thromboelastography: values and challenges. Semin Thromb Hemost. 2010 Oct;36(7): 707-11.

41. Dentali F, Squizzato A, Ageno W. The metabolic syndrome as a risk factor for venous and arterial thrombosis. Semin Thromb Hemost. 2009 Jul;35(5):451-7.

42. Favaloro EJ, McDonald D, Lippi G. Laboratory investigation of thrombophilia: the good, the bad, and the ugly. Semin Thromb Hemost. 2009 Oct;35(7):695-710.

43. Franchini M, Lippi G. Recombinant factor VIII concentrates. Semin Thromb Hemost. 2010 Jul;36(5):493-7.

44. Franchini M, Montagnana M, Targher G, Veneri D, Zaffanello M, Salvagno GL, Manzato F, Lippi G. Interpatient phenotypic inconsistency in severe congenital hemophilia: a systematic review of the role of inherited thrombophilia. Semin Thromb Hemost. 2009 Apr;35(3):307-12

45. Kitchen DP, Kitchen S, Jennings I, Woods T, Walker I. Quality Assurance and Quality Control of Thrombelastography and Rotational Thromboelastometry: The UK NEQAS for Blood Coagulation Experience. Semin Thromb Hemost. 2010 Oct;36(7):757-63.

46. Levi M, de Peuter OR, Kamphuisen PW. Management strategies for optimal control of anticoagulation in patients with atrial fibrillation. Semin Thromb Hemost. 2009 Sep;35(6):560-7.

47. Lippi G, Montagnana M, Favaloro EJ, Franchini M. Mental depression and cardiovascular disease: a multifaceted, bidirectional association. Semin Thromb Hemost. 2009 Apr;35(3):325-36.

48. Meltzer ME, Doggen C], de Groot PG, Rosendaal FR, Lisman T. The impact of the fibrinolytic system on the risk of venous and arterial thrombosis. Semin Thromb Hemost. 2009 Jul;35(5):468-77.

49. Montagnana M, Salvagno GL, Lippi G. Circadian variation within hemostasis: an underrecognized link between biology and disease? Semin Thromb Hemost. 2009 Feb;35(1):23-33.

50. Peyvandi F, Palla R, Menegatti M, Mannucci PM. Introduction. Rare bleeding disorders: general aspects of clinical features, diagnosis, and management. Semin Thromb Hemost. 2009 Jun;35(4):349-55.

51. Pisters R, de Vos CB, Nieuwlaat R, Crijns HJ. Use and underuse of oral anticoagulation for stroke prevention in atrial fibrillation: old and new paradigms. Semin Thromb Hemost. 2009 Sep;35(6):554-9.

52. Verbruggen B, van Heerde WL, Laros-van Gorkom BA. Improvements in factor VIII inhibitor detection: From Bethesda to Nijmegen. Semin Thromb Hemost. 2009 Nov;35(8):752-9.

aPublished in 2009 or 2010 and cited four or more times in 2011. List is in order of citations received; those articles receiving the same number of citations are then ordered alphabetically by first author.

Table 2 Current planned topics for future issues of Seminars in Thrombosis \& Hemostasis

- Hot topics, IV

- Quality in thrombosis and hemostasis, II

- Expert approaches to common bleeding and thrombotic problems

- Biologic role of the plasminogen-plasmin system: thrombolysis, bleeding, and beyond

- Disease-specific thrombosis

- Old and new challenges in hemophilia management

- Rare bleeding disorders

- Coagulation and the brain

listings from Seminars in Thrombosis $\mathcal{E}$ Hemostasis, the basis of the Eberhard Mammen "Most Popular" awards. ${ }^{56,57}$

Finally, a short note to confirm that the editorial team will continue to develop plans for the future content of this journal, and we are confident that we will be able to continue to bring you, the reader, the high quality journal that you have come to expect in Seminars in Thrombosis $\mathcal{E}$ Hemostasis. Currently confirmed topics for issues that we plan to publish over the next 12 or so months are listed in -Table 2. At the same time we recognize the need to retain some flexibility in our plans and to potentially add additional material of current interest and controversy as the need arises.

We look forward to another interesting year of reading in 2013 !

\section{References}

1 Favaloro EJ. The Journal Impact Factor: don't expect its demise any time soon. Clin Chem Lab Med 2009;47(11):1319-1324

2 Favaloro EJ. Measuring the quality of journals and journal articles: the impact factor tells but a portion of the story. Semin Thromb Hemost 2008;34(1):7-25

3 Althaus K, Greinacher A. MYH9-related platelet disorders. Semin Thromb Hemost 2009;35(2):189-203

4 McGlasson DL, Fritsma GA. Whole blood platelet aggregometry and platelet function testing. Semin Thromb Hemost 2009;35 (2):168-180 
5 Cattaneo M. Light transmission aggregometry and ATP release for the diagnostic assessment of platelet function. Semin Thromb Hemost 2009;35(2):158-167

6 Gisondi P, Girolomoni G. Psoriasis and atherothrombotic diseases: disease-specific and non-disease-specific risk factors. Semin Thromb Hemost 2009;35(3):313-324

7 Harrison P, Mumford A. Screening tests of platelet function: update on their appropriate uses for diagnostic testing. Semin Thromb Hemost 2009;35(2):150-157

8 Targher G, Chonchol M, Miele L, Zoppini G, Pichiri I, Muggeo M. Nonalcoholic fatty liver disease as a contributor to hypercoagulation and thrombophilia in the metabolic syndrome. Semin Thromb Hemost 2009;35(3):277-287

9 Favaloro EJ. Internal quality control and external quality assurance of platelet function tests. Semin Thromb Hemost 2009;35(2): 139-149

10 Nurden AT, Fiore M, Pillois X, Nurden P. Genetic testing in the diagnostic evaluation of inherited platelet disorders. Semin Thromb Hemost 2009;35(2):204-212

11 Pai M, Hayward CP. Diagnostic assessment of platelet disorders: what are the challenges to standardization? Semin Thromb Hemost 2009;35(2):131-138

12 Sobieraj-Teague M, O’Donnell M, Eikelboom J. New anticoagulants for atrial fibrillation. Semin Thromb Hemost 2009;35(5):515-524

13 Isbister GK. Procoagulant snake toxins: laboratory studies, diagnosis, and understanding snakebite coagulopathy. Semin Thromb Hemost 2009;35(1):93-103

14 de Moerloose P, Neerman-Arbez M. Congenital fibrinogen disorders. Semin Thromb Hemost 2009;35(4):356-366

15 Gouw SC, van den Berg HM. The multifactorial etiology of inhibitor development in hemophilia: genetics and environment. Semin Thromb Hemost 2009;35(8):723-734

16 Israels SJ. Diagnostic evaluation of platelet function disorders in neonates and children: an update. Semin Thromb Hemost 2009;35 (2):181-188

17 Weiss HJ. Impaired platelet procoagulant mechanisms in patients with bleeding disorders. Semin Thromb Hemost 2009;35(2): 233-241

18 Lippi G, Favaloro EJ, Franchini M, Guidi GC. Milestones and perspectives in coagulation and hemostasis. Semin Thromb Hemost 2009;35(1):9-22

19 Lippi G, Maffulli N. Biological influence of physical exercise on hemostasis. Semin Thromb Hemost 2009;35(3):269-276

20 Mariani G, Bernardi F. Factor VII Deficiency. Semin Thromb Hemost 2009;35(4):400-406

21 Miller JL. Glycoprotein analysis for the diagnostic evaluation of platelet disorders. Semin Thromb Hemost 2009;35(2):224-232

22 Clauser S, Cramer-Bordé E. Role of platelet electron microscopy in the diagnosis of platelet disorders. Semin Thromb Hemost 2009;35 (2):213-223

23 Favaloro EJ. Toward a new paradigm for the identification and functional characterization of von Willebrand disease. Semin Thromb Hemost 2009;35(1):60-75

24 Kershaw G, Jayakodi D, Dunkley S. Laboratory identification of factor inhibitors: the perspective of a large tertiary hemophilia center. Semin Thromb Hemost 2009;35(8):760-768

25 Mezzano D, Quiroga T, Pereira J. The level of laboratory testing required for diagnosis or exclusion of a platelet function disorder using platelet aggregation and secretion assays. Semin Thromb Hemost 2009;35(2):242-254

26 Prisco D, Grifoni E. The role of D-dimer testing in patients with suspected venous thromboembolism. Semin Thromb Hemost 2009;35(1):50-59

27 Favaloro EJ, Bonar R, Kershaw G, Duncan E, Sioufi J, Marsden K. Investigations from external quality assurance programs reveal a high degree of variation in the laboratory identification of coagulation factor inhibitors. Semin Thromb Hemost 2009;35(8):794805
28 Franchini M, Montagnana M, Manzato F, Vescovi PP. Thyroid dysfunction and hemostasis: an issue still unresolved. Semin Thromb Hemost 2009;35(3):288-294

29 Harenberg J. New anticoagulants in atrial fibrillation. Semin Thromb Hemost 2009;35(6):574-585

30 Karimi M, Bereczky Z, Cohan N, Muszbek L. Factor XIII deficiency. Semin Thromb Hemost 2009;35(4):426-438

31 Kitchen S, Jennings I, Preston FE, Kitchen DP, Woods TA, Walker ID. Interlaboratory variation in factor VIII:C inhibitor assay results is sufficient to influence patient management: data from the UK national quality external assessment scheme for blood coagulation. Semin Thromb Hemost 2009;35(8):778-785

32 Meijer P, Verbruggen B. The between-laboratory variation of factor VIII inhibitor testing: the experience of the external quality assessment program of the ECAT foundation. Semin Thromb Hemost 2009;35(8):786-793

33 Viiala NO, Larsen SR, Rasko JE. Gene therapy for hemophilia: clinical trials and technical tribulations. Semin Thromb Hemost 2009;35(1):81-92

34 Adams M. Assessment of thrombin generation: useful or hype? Semin Thromb Hemost 2009;35(1):104-110

35 Blann A, Shantsila E, Shantsila A. Microparticles and arterial disease. Semin Thromb Hemost 2009;35(5):488-496

36 Franchini M, Lippi G, Favaloro EJ. Coagulopathies and thrombosis: usual and unusual causes and associations, part I. Semin Thromb Hemost 2009;35(3):257-259

37 Lippi G, Franchini M, Favaloro EJ. Unsuspected triggers of venous thromboembolism-trivial or not so trivial? Semin Thromb Hemost 2009;35(7):597-604

38 Spreafico M, Peyvandi F. Combined factor V and factor VIII deficiency. Semin Thromb Hemost 2009;35(4):390-399

39 Tripodi A, van den Besselaar A. Laboratory monitoring of anticoagulation: where do we stand? Semin Thromb Hemost 2009;35 (1):34-41

40 Zuern CS, Lindemann S, Gawaz M. Platelet function and response to aspirin: gender-specific features and implications for female thrombotic risk and management. Semin Thromb Hemost 2009;35(3):295-306

41 Brand-Miller J, Dickinson S, Barclay A, Allman-Farinelli M. Glycemic index, glycemic load, and thrombogenesis. Semin Thromb Hemost 2009;35(1):111-118

42 Chitlur M, Lusher J. Standardization of thromboelastography: values and challenges. Semin Thromb Hemost 2010;36(7):707-711

43 Dentali F, Squizzato A, Ageno W. The metabolic syndrome as a risk factor for venous and arterial thrombosis. Semin Thromb Hemost 2009;35(5):451-457

44 Favaloro EJ, McDonald D, Lippi G. Laboratory investigation of thrombophilia: the good, the bad, and the ugly. Semin Thromb Hemost 2009;35(7):695-710

45 Franchini M, Lippi G. Recombinant factor VIII concentrates. Semin Thromb Hemost 2010;36(5):493-497

46 Franchini M, Montagnana M, Targher G, et al. Interpatient phenotypic inconsistency in severe congenital hemophilia: a systematic review of the role of inherited thrombophilia. Semin Thromb Hemost 2009;35(3):307-312

47 Kitchen DP, Kitchen S, Jennings I, Woods T, Walker I. Quality assurance and quality control of thrombelastography and rotational thromboelastometry: the UK NEQAS for blood coagulation experience. Semin Thromb Hemost 2010;36(7):757-763

48 Levi M, de Peuter OR, Kamphuisen PW. Management strategies for optimal control of anticoagulation in patients with atrial fibrillation. Semin Thromb Hemost 2009;35(6):560-567

49 Lippi G, Montagnana M, Favaloro EJ, Franchini M. Mental depression and cardiovascular disease: a multifaceted, bidirectional association. Semin Thromb Hemost 2009;35(3):325-336

50 Meltzer ME, Doggen CJ, de Groot PG, Rosendaal FR, Lisman T. The impact of the fibrinolytic system on the risk of venous and arterial thrombosis. Semin Thromb Hemost 2009;35(5):468-477 
51 Montagnana M, Salvagno GL, Lippi G. Circadian variation within hemostasis: an underrecognized link between biology and disease? Semin Thromb Hemost 2009;35(1):23-33

52 Peyvandi F, Palla R, Menegatti M, Mannucci PM. Introduction. Rare bleeding disorders: general aspects of clinical features, diagnosis, and management. Semin Thromb Hemost 2009;35(4):349-355

53 Pisters R, de Vos CB, Nieuwlaat R, Crijns HJ. Use and underuse of oral anticoagulation for stroke prevention in atrial fibrillation: old and new paradigms. Semin Thromb Hemost 2009;35(6): 554-559
54 Verbruggen B, van Heerde WL, Laros-van Gorkom BA. Improvements in factor VIII inhibitor detection: From Bethesda to Nijmegen. Semin Thromb Hemost 2009;35(8):752-759

55 Hayward CP, Favaloro EJ. Diagnostic evaluation of platelet disorders: the past, the present, and the future. Semin Thromb Hemost 2009;35(2):127-130

56 Favaloro EJ. 2011 Eberhard F. Mammen award announcements. Semin Thromb Hemost 2011;37(5):431-439

57 Favaloro EJ. 2012 Eberhard F. Mammen award announcements. Semin Thromb Hemost 2012;38(5):425-432 